\title{
STRATEGI PERSONAL SELLING DALAM PELAKSANAAN SISTEM KEAGENAN PERISAI BPJS KETENAGAKERJAAN DI WILAYAH KALIMANTAN
}

\author{
Yunglinna Ria \\ Sekolah Tinggi Ilmu Ekonomi Pancasetia Banjarmasin \\ Jl. Ahmad Yani Km. 5.5 Banjarmasin \\ yunglinna.ria@gmail.com
}

\begin{abstract}
Abstrak: Jaminan sosial adalah hak setiap warga negara, namun rendahnya kesadaran masyarakat akan pentingnya jaminan sosial dan kondisi geografis Indonesia menjadi tantangan. BPJS Ketenagakerjaan membutuhkan mitra untuk mengakuisisi tenaga kerja di Indonesia, yaitu agen perisai. Oleh karena itu, strategi personal selling penting untuk dimiliki oleh seorang agen. Penelitian ini bertujuan untuk mengetahui strategi personal selling agen perisai BPJS Ketenagakerjaan di wilayah Kalimantan, menganalisis kendala yang dihadapi, serta mengetahui upaya yang dilakukan Kantor Cabang dalam penanganan kendala-kendala tersebut. Penelitian ini merupakan penelitian deskriptif kualitatif dengan metode pengumpulan data yaitu wawancara secara mendalam dengan 11 agen perisai. Dari hasil penelitian ditemukan bahwa personal selling diterapkan dalam memasarkan program BPJS Ketenagakerjaan yaitu dengan tahapan prospek, pra-pendekatan, sosialisasi dan demonstrasi, mengatasi keberatan, penutupan dan tindaklanjut dan pemeliharaan. Beberapa kendala ditemukan hampir di setiap tahapan personal selling. Kantor Cabang berupaya untuk mengatasi kendala yang dihadapi seperti pembinaan agen perisai dan memberikan fasilitas yang dibutuhkan untuk akuisisi.
\end{abstract}

Kata kunci : strategi personal selling, agen perisai, BPJS Ketenagakerjaan. 


\section{Latar Belakang}

Penyelenggaraan program jaminan sosial merupakan salah satu tanggung jawab dan kewajiban negara untuk memberikan perlindungan sosial ekonomi kepada masyarakat. Sesuai dengan kondisi kemampuan keuangan negara. Indonesia seperti halnya negara berkembang lainnya, mengembangkan program jaminan sosial berdasarkan funded social security, yaitu jaminan sosial yang didanai oleh peserta dan masih terbatas pada masyarakat pekerja di sektor formal (BPJS Ketenagakerjaan, 2015).

Tingkat kepesertaan BPJS Ketenagakerjaan yang masih rendah menjadi perhatian khusus bagi jajaran manajemen BPJS Ketenagakerjaan. Rendahnya pengetahuan masyarakat dan kesadaran akan pentingnya jaminan sosial menjadi salah satu faktor penyebab masih rendahnya tingkat kepesertaan BPJS Ketenagakerjaan. Tercatat hingga Desember 2019, 55,2 juta pekerja atau mencakup $60,7 \%$ dari seluruh pekerja Indonesia telah terdaftar sebagai peserta (Kompas, 2019).

Berbagai macam upaya untuk meningkatkan kepesertaan telah dilakukan BPJS Ketenagakerjaan. Adapun kondisi geografis yang terlalu luas terdiri dari berbagai pulau memang tidak memungkinkan untuk membuka kantor layanan di setiap kota. Sebanyak 514 kabupaten/kota belum memungkinkan untuk dibangun kantor demi kepentingan efektivitas. BPJS Ketenagakerjaan kemudian membentuk perisai untuk meningkatkan kepesertaan. Perisai merupakan agen sosial yang diciptakan untuk meningkatkan penetrasi dari produk-produk BPJS Ketenagakerjaan.
Agen perisai ini untuk membantu menjangkau seluruh pekerja yang ada di Tanah Air. Perisai atau agen ini akan menjadi penggerak jaminan sosial sekaligus wakil dari BPJS Ketenagerjaan untuk berinteraksi, memberikan sosialisasi ataupun nasihat kepada masyarakat (BPJS Ketenagakerjaan, 2017). Kondisi geografis wilayah Kalimantan merupakan tantangan tersendiri untuk BPJS Ketenagakerjaan wilayah Kalimantan. Terbatasnya akses komunikasi di daerah-daerah pedesaan juga menjadi tantangan dalam melaksanakan amanah untuk melindungi seluruh pekerja di Indonesia. Wilayah Kalimantan yang luas mengakibatkan sulitnya penetrasi program jaminan sosial ketenagakerjaan ke pelosok-pelosok Kalimantan ditambah lagi dengan jumlah personil yang terbatas.

Adapun karakteristik agen perorangan adalah bergerak perorangan dalam memasarkan produknya dengan target nasabah yang ditujukan kepada perorangan pula. Penjualan tatap muka ini dikenal dengan sebutan personal selling. Jadi dapat disimpulkan bahwa tidak mungkin tenaga personal selling dapat melaksanakan tugasnya dengan baik jika tidak memiliki kemampuan komunikasi antar pribadi yang baik, ditambah dengan ilmu pemasaran (Kompas, 2016). Penelitian ini diharapkan dapat memberikan gambaran mengenai personal selling agen perisai dalam pelaksanaan keagenan di daerah-daerah khususnya wilayah Kalimantan. 


\section{Studi Literatur}

\section{Jaminan Sosial Ketenagakerjaan}

Jaminan sosial merupakan program yang dilaksanakan oleh hampir seluruh negara di dunia. Setiap negara tersebut memiliki program yang disesuaikan dengan kondisi yang dihadapi seperti faktor kemampuan finansial, faktor demografi, politik, serta sosial. Program jaminan sosial di setiap negara dikelola oleh suatu organisasi penyelenggara jaminan sosial yang ditunjuk oleh Pemerintah (Arianto, 2017).

Berdirinya

Badan

Penyelenggara Jaminan Sosial (BPJS) Ketenagakerjaan per 1 Januari 2014 sebagai bentuk transformasi dari PT. Jamsostek (Persero) menjadi salah upaya riil pemerintah dalam mewujudkan jaminan sosial tersebut. Terbentuknya BPJS Ketenagakerjaan itu didasarkan pada Undang-Undang Nomor 40 Tahun 2004 tentang Sistem Jaminan Sosial Nasional dan UndangUndang Nomor 24 Tahun 2011 tentang Badan Penyelenggara Jaminan Sosial. Terhitung sejak 1 Juli 2015, BJPS Ketenagakerjaan beroperasi penuh untuk menyelenggarakan Jaminan Sosial Bidang Ketenagakerjaan dalam bentuk Jaminan Hari Tua (JHT), Jaminan Kecelakaan Kerja (JKK), Jaminan Pensiun (JP) dan Jaminan Kematian (JKm). Salah satu perubahan mendasar dari transformasi PT. Jamsostek (Persero) menjadi BJPS Ketenagakerjaan itu terletak pada aspek perluasan cakupan kepesertaan dan orientasi pelayanannya. Dalam hal ini, cakupan peserta BPJS Ketenagakerjaan meliputi semua pekerja di sektor formal maupun informal, meskipun prioritas utamanya tertuju pada pekerja di sektor formal (Silaban \& Badikenita, 2017).

Perisai

Agen Perisai (Penggerak Jaminan Sosial Indonesia) merupakan perpanjangan tangan BPJS Ketenagakerjaan yang menggunakan skema keagenan dalam mengakuisisi peserta. Menurut Kamus Besar Bahasa Indonesia (KBBI), agen adalah orang atau perusahaan perantara yang mengusahakan penjualan bagi perusahaan lain atas nama pengusaha atau perwakilan. Agen Perisai BPJS Ketenagakerjaan mempunyai beberapa tugas diantarannya melakukan sosialisasi, akuisisi, dan pengelolaan kepesertaan program Jaminan Sosial Ketenagakerjaan. Konsep agen Perisai ini merupakan adaptasi dari skema bisnis Jimukumiai dan Sharoushi yang dijalankan di Jepang.

Jumikumiai sendiri berarti sebagai organisasi yang mempunyai perizinan dan sertifikat untuk mengakuisisi peserta dan mengumpulkan iuran, akan diadopsi menjadi Sentra Komunikasi Jaminan Sosial (SKJS). Sedangkan Sharoushi, merupakan profesi ahli ataupun agen perpanjangan tangan dari Jimukumiai untuk melakukan proses administrasi akuisisi kepesertaan sekaligus memberikan mediasi, advokasi dan informasi tentang program dan manfaat jaminan sosial (Finansialku, 2017).

\section{Pengertian Pemasaran (Marketing)}

Pemasaran adalah proses dimana perusahaan menciptakan nilai bagi pelangan dan membangun hubungan pelanggan yang kuat untuk menangkap kembali nilai dari pelanggan. Menurut asosiasi pemasaran Amerika Kotler dan Keller, 
pemasaran adalah satu fungsi organisasi dan seperangkat proses untuk menciptakan, mengkomunikasikan, dan menyerahkan nilai kepada pelanggan dan mengelola hubungan dangan pelanggan dengan cara menguntungkan organisasi dan para pemilik sahamnya (Kotler dkk, 2012).

Pemasar harus mampu untuk menciptakan nilai pelanggan dan mengelola hubungan yang baik dengan pelanggan. Untuk menciptakan nilai pelanggan, pemasar harus :

1. Mengerti pasar dan mengetahui apa yang dibutuhkan dan diinginkan oleh pelanggan

2. Pemasar harus merancang strategi pemasaran untuk mendapatkan dan mempertahankan pelanggan. Tujuannya adalah menarik, mempertahankan, dan menumbuhkan pelanggan sasaran dengan menciptakan komunikasi keunggulan nilai bagi pelanggan.

3. Membangun program pemasaran yang terintegrasi untuk mendapatkan nilai tambah (khusus) di mata pelanggan, yaitu sarana bauran pemasaran yang dikelompokkan menjadi empat kelompok yaitu : product (produk), price (harga), place (tempat), dan promotion (promosi).

4. Membangun hubungan baik yang menguntungkan dan dapat menciptakan kepuasan pelanggan

5. Menangkap kembali nilai pelanggan yang telah dibangun untuk mendapatkan keuntungan (Kotler dkk, 2012).

\section{Strategi Pemasaran}

Menurut Tjiptono, strategi marketing atau strategi pemasaran merupakan sebuah alat yang mendasar dan fundamental yang didesain untuk mencapai tujuan dari perusahaan dengan cara mengembangkan daya saing yang unggul dan berkesinambungan. Hal tersebut dimaksudkan untuk bisa memberikan pelayanan terbaik bagi sasaran target dari usaha tersebut (Tjiptono, 2002).Strategi pemasaran berfokus pada tujuan jangka panjang perusahaan dan melibatkan perusahaan dan melibatkan perencanaan programprogram pemasaran untuk mewujudkan tujuan perusahaan. Strategi pemasaran adalah proses perencanaan dan implementasi kebijakan perusahaan untuk mewujudkan tujuan-tujuan perusahaan yang sesuai dengan visi perusahaan (Hermawan, 2012).

Bauran Pemasaran (Marketing Mix) Kotler (2008) mendefinisikan pemasaran sebagai suatu rangkaian tujuan dan sasaran, kebijakan dan aturan yang menjadi arah kepada usaha-usaha pemasaran perusahaan dalam menghadapi lingkungan dan keadaan pesaing yang selalu berbeda. Pemasaran merupakan suatu proses sosial manajerial yang di dalamnya individu dan kelompok mendapatkan apa yang mereka butuhkan dan inginkan dengan menciptakan, menawarkan dan mempertukarkan produk yang bernilai dengan pihak lain. Konsep ini yang mendasari definisi pemasaran diantaranya: kebutuhan (needs), keinginan (want) dan permintaan (demands).

Bentuk-bentuk bauran promosi memiliki fungsi yang sama, tetapi bentuk-bentuk tersebut dapat dibedakan berdasarkan tugas-tugas khususnya. Beberapa tugas khusus itu atau sering disebut bauran promosi 
(promotion mix, promotion blend, communication mix) adalah sebagai berikut (Tjiptono, 2002):

a. Personal selling, adalah komunikasi langsung (tatap muka) antara penjual dan calon pelanggan untuk memperkenalkan suatu produk kepada calon pelanggan.

b. Mass selling, merupakan pendekatan yang menggunakan media komunikasi untuk menyampaikan informasi kepada khalayak ramai dalam satu waktu.

c. Promosi penjualan, adalah bentuk persuasi langsung melalui penggunaan berbagai insentif yang dapat diatur untuk merangsang pembelian produk dengan segera dan atau meningkatkan jumlah barang yang dibeli pelanggan.

d. Public relations, merupakan upaya komunikasi meyeluruh dari suatu perusahaan untuk mempengaruhi persepsi, opini, keyakinan, dan sikap berbagai kelompok terhadap perusahaan tersebut.

e. Direct marketing, adalah sistem pemasaran yang bersifat interaktif, yang memanfaatkan satu atau beberapa media iklan untuk menimbulkan respon yang terukur dan atau transaksi di sembarang lokasi.

\section{Personal selling}

Personal selling adalah bentuk komunikasi langsung antara seorang penjual dengan calon pembelinya (person-to-person communication). Dalam hal ini, penjual berupaya untuk membantu atau membujuk calon pembeli untuk membeli produk yang ditawarkan. Melalaui interaksi secara langsung ini, maka pihak penjual dapat melihat atau mendengarkan respon pembeli. Dalam hal ini, pejual dapat langsung memodifikasi informasi yang harus disampaikannya setelah menerima tanggapan dari calon pembeli (Morissan, 2010).

Aktivitas personal selling ialah berupa kegiatan yang dilakukan agen dalam melakukan pendekatan pada calon peserta serta meyakinkan calon peserta terkait keuntungan apabila membeli produk hingga menutup penjualan. Adapun tahapan aktivitas personal selling menurut Kotler dan Armstrong (2012) memiliki beberapa tahap yaitu:

1. Prospecting and Qualifiying Tahap ini merupakan langkah pertama dalam menjual adalah mengidentifikasi calon nasabah. Biasanya menyeleksi calon nasabah dilakukan dengan cara menghubungi mereka melalui pesan atau telpon untuk mengetahui tingkat ketertarikan, minat beli dan kemampuan finansial dari calon nasabah.

2. Preaproach

Fase dimana tenaga penjualan mencari informasi mengenai calon nasabah dari perusahaan tentang kebutuhan dari calon nasabah, siapa yang memegang peranan dalam memutuskan pembelian, dan lainnya.

3. Presentation and Demonstration :

Fase dimana tenaga penjual menceritakan tentang produk kepada pembeli dengan mengunakan pendekatan fitur (features), keunggullan (advantages), manfaat (benefits), dan nilai (value). 
4. Overcoming Objections :

Fase dimana tenaga penjual mengatasi masalah yang dihadapi konsumen yang dapat mengalangi proses pembelian yang terbagi menjadi dua yaitu hambatan psikologi (prefrensi merek lain, apatis, ide yang ditetapkan sebelumnya, dan lainnya) dan hambatan logis (harga, waktu pengantaran, dan karakteristik produk atau perusahaan).

5. Closing :

Fase dimana pembeli melakukan tindakan nyata, keputusan atau masukan, dan pertanyaan.

6. Follow Up and Maintenance : Hal ini sangatlah penting utuk memastikan kepuasan pelanggan dan pembelian ulang. Secara langsung setelah closing, tenaga penjual harus memberitauhkan semua keperluan yang detail seperti waktu pengantaran, ketentuan pembelian, dan hal lain yang penting bagi konsumen.

\section{Metode Penelitian}

\section{Rancangan Penelitian}

Penelitian ini didesain sebagai penelitian deskriptif kualitatif, yaitu jenis penelitian yang memberikan gambaran atau penjabaran tentang suatu objek penelitian berdasarkan karakteristik yang dimiliki. Hasil penelitian yang diperoleh akan memberikan gambaran mengenai strategi personal selling yang digunakan oleh agen perisai BPJS Ketenagakerjaan.

\section{Definisi Operasional Variabel Penelitian}

Personal selling adalah komunikasi langsung (tatap muka) antara penjual dan calon pelanggan untuk memperkenalkan suatu produk kepada calon pelanggan dan membentuk pemahaman terhadap produk sehingga mereka kemudian akan mencoba membelinya.

Personal selling memiliki peran yang sangat besar terhadap purchase intention konsumen, dimana persepsi konsumen terhadap sales person termasuk kemampuannya dalam menarik perhatian konsumen telah mempengaruhi niat konsumen untuk melakukan pembelian. Mengenai hal tersebut, Gunasekaran at all, (2015) menggunakan empat indikator untuk mengukur efektivitas personal selling dalam meningkatkan minat konsumen untuk melakukan pembelian yaitu:

1. Kemampuan Komunikasi (Communication Ability)

Kemampuan komunikasi menunjukkan kemampuan personal untuk menjalin komunikasi yang baik dengan konsumen, memiliki sikap yang sopan, mampu mengendalikan emosi.

2. Pengetahuan Produk (Product Knowledge)

Pengetahuan produk menunjukkan kemampuan sales person dalam menjelaskan karakteristik produk, manfaat produk, serta mampu menjawab berbagai pertanyaan yang diajukan oleh konsumen mengenai produk yang ditawarkan.

3. Kreativitas (Creativity) 
Kreativitas merujuk pada keterampilan sales person dalam memasarkan produk, menggunakan berbagai metode komunikasi dalam menarik perhatian konsumen, serta memiliki kesabaran ketika menawarkan produk kepada konsumen.

4. Empati (Empathy)

Empati merujuk pada kemampuan sales person untuk memberikan perhatian individual kepada konsumen, sungguh-sungguh

mengutamakan kepentingan konsumen dan pemahaman terhadap kebutuhan konsumen serta kemampuan sel persen dalam memberikan solusi terhadap masalah yang dihadapi konsumen.

Adapun yang menjadi faktor sukses dalam personal selling yang diteliti mengacu pada faktor-faktor seperti yang diidentifikasi oleh Kotler dan Armstrong (2012) yang terdiri dari

a. Prospecting adalah tahapan dimana karyawan melakukan identifikasi pada konsumen atau nasabah potensial.

b. Pre-approach adalah tahapan dimana karyawan mulai secara aktif untuk memperoleh informasi lebih detail mengenai konsumen atau nasabah potensial.

c. The sales presentation and demonstration adalah tahapan dimana karyawan mempresentasikan produk atau jasa secara langsung kepada konsumen atau nasabah.

d. Overcoming objection adalah tahapan dimana agen menunjukkan memberikan atau melakukan simulasi kepada konsumen atau nasabah atas produk atau jasa perusahaan secara objektif.

e. Closing adalah tahapan dimana karyawan meminta meminta kepada mengambil keputusan untuk membeli produk atau jasa perusahaan.

f. Follow up service adalah tahapan dimana karyawan menjalin atau Membangun hubungan dengan konsumen atau nasabah serta proses pembelian produk atau jasa perusahaan

\section{Jenis dan Sumber Data Jenis Data}

Adapun jenis data dalam penelitian ini adalah data kualitatif yang diperoleh dari hasil wawancara dengan 11 orang agen perisai.

\section{Sumber Data}

Sumber data dalam penelitian ini yaitu data primer dan data sekunder. Data primer merupakan data utama yang diperoleh peneliti yang merupakan hasil pengumpulan data melalui wawancara atau kuesioner yang bertujuan untuk memperoleh informasi langsung dari informan. Data sekunder adalah data pelengkap, yang diperoleh dari studi pustaka, literatur, jurnal ilmiah ataupun sumber lain yang berkaitan dan relevan dengan objek penelitian yang akan diteliti.

\section{Populasi}


Populasi dalam penelitian ini ada seluruh agen perisai BPJS Ketenagakerjaan di seluruh Kalimantan (Kalimantan Barat, Kalimantan Tengah, Kalimantan Selatan, Kalimantan Timur, dan Kalimantan Utara) yang berjumlah 386 orang.

\section{Teknik Pengumpulan Data}

Teknik pengumpulan data yang dilakukan dalam penelitian ini adalah melalui wawancara atau kuesioner yang bertujuan untuk memperoleh informasi langsung dari informan.

\section{Teknik Analisis Data}

Data yang diperoleh akan
dianalisis dan dikaji melalui
pendekatan kualitatif naratif, yaitu
dengan mengungkapkan data,
menguraikan data dengan
mendeskriptifkan data yang diperoleh
dari penelitian baik data primer
maupun data sekunder dengan
menggunakan bahasa yang mudah
dimengerti dan dipahami kemudian
data yang diperoleh diuraikan serta
dikembangkan berdasarkan teori yang
ada.

\section{Hasil Penelitian dan Pembahasan}

Dalam penelitian ini informan diberikan 18 pertanyaan yang dikelompokkan dalam 8 bagian yang akan menggambarkan latar belakang agen perisai, penerapan personal selling dalam kegiatan keagenan perisai, dan kendala yang dialami, hingga peran kantor cabang dalam mendukung pelaksanaan keagenan perisai di lapangan.

Peneliti memberikan pertanyaan untuk mengetahui latar belakang dari agen perisai karena ingin melihat apakah pekerjaan atau posisi di masyarakat mempengaruhi hasil capaian dari agen tersebut. Berdasarkan dari hasil wawancara dengan informan didapati sebagian dari informan merupakan orang yang dikenal di masyarakat, meskipun tidak menempati posisi tertentu di masyarakat, namun ternyata relasi yang banyak juga memiliki pengaruh yang positif terhadap pencapaian dari agen tersebut.

Informan yang memiliki relasi dengan pimpinan atau koordinator dari komunitas memiliki akses untuk mengakuisisi kelompok tersebut lebih mudah, karena pada umumnya anggota ataupun masyarakat akan mengikuti arahan dari sang pemangku kebijakan (seperti kepala desa maupun ketua kelompok/ organisasi). Disinilah salah satu peranan agen perisai dalam kemitraannya dengan BPJS Ketenagakerjaan, yaitu untuk menghubungkan instansi dengan masyarakat. Hal ini sejalan dengan salah satu peranan dari personal selling menurut Kotler dan Amstrong (2014) mengenai yaitu Linking The Company with It's Customer dimana tenaga penjual dapat digambarkan sebagai jembatan yang menghubungkan perusahaan dengan pelanggannya. Pertama tenaga penjual mempresentasikan perusahaan kepada pelanggan. Mereka menemukan dan menggarap pelanggan baru dan mengkomunikasikan informasi tentang produk yang ditawarkan oleh perusahaan. Berdasarkan hasil wawancara, agen yang memiliki keberanian dan kemampuan untuk membuka jaringan baru atau berinteraksi dengan orang-orang baru untuk menemukan potensi, biasanya memiliki hasil capaian yang lebih 
dibandingkan agen yang berkutat dengan zona atau lingkungannya saja.

\section{Strategi Personal selling}

Personal selling terdiri dari interaksi antara pribadi dengan pelanggan dan calon pelanggan untuk membuat penjualan dan mempertahankan hubungan dengan pelanggan (Kotler \& Amstrong, 2014). 1. Tahap prospek dan kualifikasi (prospecting and qualifying)

Prospecting (Pencarian) adalah tahapan dimana karyawan melakukan identifikasi pada konsumen atau nasabah potensial. Tahap ini merupakan tahap dimana agen melakukan pengamatan mengenai potensi peserta dapat dilihat dari segi kebutuhan akan produk dan kemampuan finansial calon peserta tersebut. Tenaga penjual juga perlu mengetahui bagaimana calon peserta yang memenuhi kriteria seperti merupakan pekerja, tidak boleh mendaftarkan peserta dalam keadaan sakit menahun (dengan kesengajaan) dan usia peserta tidak lebih dari 59 tahun.

Ini adalah tahap dimana tenaga penjual mengidentifikasi pelanggan potensial berkualitas. Agen perisai melakukan pendekatan dengan pelanggan potensial yang tepat merupakan hal penting untuk sukses dalam menjual. Awal mula terjun sebagai agen perisai, hampir semua informan memulai dari orang-orang yang ada disekitarnya, mulai dari keluarga, tetangga hingga temanteman.

Berdasarkan hasil wawancara, pada tahapan prospecting setiap agen memiliki cara masing-masing yang menyesuaikan dengan calon peserta tersebut. Dalam dunia marketing, tidak hanya kemampuan berbicara yang dibutuhkan untuk memulai percakapan dengan calon peserta. Pada tahapan ini kemampuan mendengarkan yang baik juga tidak kalah penting karena adanya interaksi antara agen dan peserta. Interaksi tersebut akan membantu kita untuk mengetahui kebutuhan calon peserta akan produk kita dan bagaimana kita menyisipkan produk dalam percakapan.

2. Tahap pendekatan (preapproach)

Pada tahap pendekatan, tenaga penjual harus mengerti bagaimana bertemu dan menyapa pembeli serta menjalin hubungan sebagai permulaan yang baik. Dalam tahap ini termasuk di dalamnya mengenai penampilan tenaga penjual, cara memulai pembukaan, dan cara untuk menindaklanjuti. Kelancaran dialek dan adanya perasaan kesamaan dalam nilai kebudayaan sangat bermanfaat dalam meningkatkan komunikasi dengan pembeli.

Cara pendekatan yang dilakukan hampir seluruh informan yaitu melalui percakapan santai dan hadir secara personal, tidak sedikit yang melakukannya secara informal. Hal tersebut dianggap lebih mudah diterima oleh masyarakat pada umumnya. Beberapa informan juga mencoba melakukan pendekatan dengan menghampiri orang-orang yang menjadi pimpinan atas suatu daerah atau komunitas tertentu. Berdasarkan hasil wawancara, peneliti menemukan pada tahap ini informan memilih untuk membuka percakapan santai atau informal bahkan tidak sedikit yang lebih menggunakan bahasa daerah agar lebih mudah diterima. Hampir seluruh informan 
memiliki target kepesertaan perorangan yang membuat agen harus mampu melakukan pendekatan secara personal.

$\begin{array}{lcc}\text { 3. Tahap } & \text { presentasi } & \text { dan } \\ \text { demonstrasi } & \text { (presentation } & \text { and } \\ \text { demonstration) } & & \end{array}$

Pada tahap presentasi dan demonstrasi, tenaga penjual menyampaikan "cerita" mengenai produk kepada konsumen, mempresentasikan keuntungan untuk konsumen dan menunjukkan bagaimana produk tersebut dapat memberikan solusi terhadap permasalahan yang dimiliki konsumen. Beberapa hal yang tidak konsumen sukai dari tenaga penjual adalah suka memaksa, lambat, bohong, tanpa persiapan, dan tidak teratur. Kualitas yang paling bernilai yakni adanya rasa empati, pendengar yang baik, jujur, dapat diandalkan, ketelitian, dan tindak lanjutnya. Kotler, Armstrong, Ang, Leong, Tan dan Tse mengutip dari buku "Do customers hate salespeople?" karya Betsey Cummings dan "Draw Them In" karya Don Chambers yang menyebutkan bahwa tenaga penjual yang baik tahu bagaimana menjual, tapi hal yang lebih penting lagi mereka tahu bagaimana mendengar dan membangun hubungan baik yang kuat dengan konsumen. Setiap agen harus memiliki kemampuan untuk menyesuaikan diri dengan calon peserta yang dihadapi.

Beberapa informan mengungkapkan bahwa untuk di daerah, potensi calon peserta sebagian besar memiliki tingkat pendidikan yang rendah yang mengakibatkan agen harus mampu menjelaskan dengan bahasa yang paling sederhana dan memiliki kesabaran yang lebih untuk mampu mengedukasi masyarakat.

4. Tahap mengatasi keberatan (overcoming objection)

Fase dimana tenaga penjual mengatasi masalah yang dihadapi konsumen yang dapat mengalangi proses pembelian yang terbagi menjadi dua yaitu hambatan psikologi (prefrensi merek lain, apatis, ide yang ditetapkan sebelumnya, dan lainnya) dan hambatan logis (harga, waktu pengantaran, dan karakteristik produk atau perusahaan).

Konsumen hampir selalu memiliki keberatan selama presentasi atau ketika diminta melakukan pemesanan. Permasalahan bisa berupa hal logis, psikologis, dan pertanyaan/ keberatan yang tidak diungkapkan. Dalam menangani keberatan/ keluhan, tenaga penjual harus menggunakan pendekatan positif, menggali keberatan yang tersembunyi, meminta konsumen untuk mengklarifikasi keberatan, menggunakan keberatan sebagai peluang untuk memberikan informasi lebih kepada konsumen, dan menjadikan keberatan tersebut menjadi alasan bagi konsumen untuk melakukan pembelian. Informan menyampaikan dalam tahapan ini, jika kita telah membangun hubungan yang baik dan erat dengan calon peserta maupun peserta, maka ketika terdapat komplain atau sanggahan, orang tersebut akan lebih mudah mengerti dan menerima jawaban atau apapun yang kita sampaikan.

5. Tahap penutupan (closing)

Tahap ini tenaga penjual mencoba untuk mendorong terjadinya penjualan. Pada wawancara dengan agen, ditemui bahwa agen pada 
tahapan ini berusaha untuk memberikan penawaran dengan meyakinkan calon peserta bahwa mereka akan memberikan harga terbaik dengan segala kemudahan dalam proses pendaftaran (jemput bola). Seringkali calon peserta yang masih berpikir dalam mengambil keputusan pembelian dapat terpancing ketika disampaikan testimonitestimoni dari peserta yang telah mendapatkan manfaat. Terdapat juga tenaga penjual yang berusaha dengan meningkatkan emosi pelanggan dengan menciptakan rasa butuh untuk membeli produk tersebut seperti agen mengajak peserta untuk membayangkan apa yang akan terjadi seandainya resiko-resiko kerja menghampiri mereka. Pesan yang tersampaikan ke calon peserta bisa menciptakan rasa fear of missing out yang membuat peserta tidak berpikir lagi untuk menunda kepesertaan.

Namun dalam pelaksanaan, tampaknya masih terdapat agen yang memiliki rasa kurang percaya diri yang berdampak pada kurang berhasil pada tahapan ini. Mereka biasanya merasa kurang percaya diri, merasa bersalah menanyakan untuk dilakukan pemesanan, atau gagal untuk menyadari momen yang tepat untuk mendorong penjualan. Agen merasa tidak nyaman untuk menanyakan keputusan pembelian karrna tidak ingin memberikan kesan memaksa. Hal tersebut dapat diatasi dengan motivasi dan pembinaan dari ARK. Dari sisi agen/ tenaga penjual pun harus memiliki keinginan untuk meningkatkan kapasitas diri dengan terus belajar dan berusaha untuk keluar dari zona nyaman, karena pada tahapan ini pun dapat dilakukan dengan penggunaan pilihan kata yang tepat sehingga tidak terkesan memaksa bagi calon peserta yang di prospek.

6. Tahap tindaklanjut dan pemeliharaan (follow up and maintenance)

Tahap terakhir dalam proses penjualan adalah follow-up atau tindak lanjut. Hal tersebut diperlukan untuk memastikan kepuasan konsumen dan kembali menjalin hubungan bisnis. Tepat setelah proses persetujuan penjualan, tenaga penjual perlu melengkapi hal-hal lainnya seperti hal mengenai pendistribusian, syarat penjualan, dan masalah-masalah lainnya. Tenaga penjual kemudian sebaiknya menjadwalkan untuk melakukan panggilan tindak lanjut ketika menerima pesanan, untuk memastikan bahwa instalasi, instruksi dan layanan telah dilakukan dengan baik. Tindakan ini akan menghindari berbagai macam masalah, meyakinkan pembeli mengenai tujuan tenaga penjual, dan mengurangi kekhawatiran konsumen yang akan muncul setelah terjadi penjualan.

Berdasarkan hasil wawancara tahapan ini secara keseluruhan dapat dieksekusi dengan baik oleh agen perisai. Apabila calon peserta memutuskan untuk mendaftar, maka agen dengan segera menginfokan kelengakapan yang diperlukan. Meskipun terdapat peserta yang menunda keputusan mendaftar dengan alasan berpikir ataupun diskusi dengan keluarga, salah satu informan memiliki cara jitu yaitu dengan datang kerumah calon peserta dan berinteraksi dengan keluarganya. Cara tersebut ternyata cukup efektif untuk membangun hubungan dan rasa percaya terhadap agen. Hal tersebut bisa ditiru untuk 
agen lainnya, meskipun dalam prakteknya kemungkinan akan membutuhkan waktu dan usaha yang lebih banyak.

Keunggulan lainnya dari sistem keagenan perisai ini yaitu dalam bentuk hubungan atau komunikasi yang rutin dengan peserta. Proses reminder bulanan dan pembayaran iuran membuat agen secara langsung atau tidak langsung berinteraksi dengan peserta secara personal. Interaksi yang rutin dengan peserta tersebut membuat agen dapat memastikan kepuasan peserta selama masa kepesertaannya. Rutinitas tersebut juga berfungsi untuk membangun rasa percaya peserta kepada agen, karena hubungan yang terjalin dan menciptakan rasa aman dan percaya setelah menjadi peserta yang tentu saja akan berdampak pada loyalitas peserta. Kendala dan permasalahan pun dapat diatasi sedari dari dini jika muncul keluhan atau hal sejenisnya dari peserta.

\section{Kendala dalam Pelaksanaan Keagenan Perisai}

Dalam pelaksanaan keagenan perisai di lapangan tentu terdapat kendala-kendala yang dihadapi oleh pelaksananya, dalam hal ini adalah agen perisai. Kendala yang dihadapi oleh agen sangat beragam mulai dari kemampuan komunikasi dan relasi, aplikasi, akses jalan, hingga masyarakat yang berasal dari beragam suku yang tentunya memiliki karakteristik yang berbeda di setiap daerahnya. Adapun yang menjadi kendala bagi agen perisai penulis uraikan pada setiap tahapan personal selling, sebagai berikut :

1. Tahap Prospek
Pada tahapan ini banyak agen yang merasa tidak ada kendala saat pelaksanaannya. Hal tersebut dikarenakan pada tahapan awal ini mereka memulai dengan orang di sekitar yang telah dikenal seperti keluarga dan teman-teman. Namun, berbeda halnya dengan agen perisai yang mencari peserta/ prospek diluar dari lingkungannya. Pada saat melakukan prospek diluar lingkungan sehari-harinya tidak jarang agen tersebut dipertanyakan resmi atau tidak karena belum memiliki seragam yang merepresentasikan Instansi BPJS Ketenagakerjaan, meskipun sudah menggunakan ID Card resmi dari Kantor Cabang. Hal serupa dialami oleh beberapa agen yang telah saya wawancarai, tidak disediakannya seragam resmi dari pusat/ kantor cabang tertentu membuat informan akhirnya membuat seragam sendiri dengan biaya sendiri demi memperlancar saat beraksi di lapangan.

2. Tahap Prapendekatan

Tahapan prapendekatan ini seringkali menjadi kendala bagi agen perisai adalah jarak dan jaringan komunikasi, hingga kondisi masyarakatnya. Kondisi geografis Kalimantan yang sangat luas dan masih ada daerah dengan akses jalan yang masih buruk di beberapa lokasi merupakan tantangan tersendiri bagi agen perisai, bahkan bagi Kantor Cabang setempat. Akses terbatas yang bahkan perlu menyeberang menggunakan kapal tentu saja membutuhkan biaya ekstra untuk menjangkau ke daerah tersebut. Ditambah lagi ketika sampai di lokasi ternyata disana akses jaringan komunikasi terbatas dan tidak ada 
ATM/ kios transaksi keuangan/ perbankan yang akan jadi penghambat dalam keberlanjutan/ sustainability pembayaran iuran peserta. Kendalakendala yang disebutkan tadi merupakan kendala yang sudah tidak asing lagi di wilayah-wilayah tertentu yang memang memiliki tantangan secara geografis, yang kemungkinan tidak dialami di wilayah perkotaan atau daerah yang sudah maju secara ekonomi. Bagi agen yang berada di daerah perkotaan, beberapa merasakan tantangan lainnya ketika melakukan pendekatan dengan bpu secara door-todoor karena akan membutuhkan waktu dan biaya extra untuk operasional.

Kendala lainnya yang sering dihadapi agen saat melakukan pendekatan yaitu kurang baiknya citra BPJS Kesehatan yang cukup berdampak kepada BPJS Ketenagakerjaan. Adapula yang masih menyamakan Program jaminan sosial ketenagakerjaan ini dengan asuransi swasta. Penjelasan yang mendalam sudah cukup untuk meluruskan kesalahpahaman tersebut, namun butuh usaha ekstra untuk meyakinkan kembali masyarakat yang pernah punya pengalaman buruk dengan asuransi swasta. Pada sektor kepesertaan Penerima Upah (toko, badan usaha kecil menengah) ternyata masih banyak masyarakat yang tidak familiar dengan BPJS Ketenagakerjaan atau yang dulunya disebut Jamsostek. Pemilik usaha banyak yang merasa ragu dan bertanya-tanya apakah benar kepesertaannya besifat wajib, padahal pelaksanaan jaminan sosial telah diatur dalam UU No 24 Tahun 2011 tentang Badan Penyelenggara Jaminan Sosial, yang merupakan aturan yang sama dengan kewajiban kepesertaan BPJS Kesehatan.

3. Tahap Sosialisasi dan Demonstrasi

Berdasarkan hasil wawancara pada tahapan ini ditemui kendala dalam komunikasi atau bahasa. Kendala ini biasanya dialami oleh agen-agen yang melakukan prospekakuisisi hingga ke daerah pelosok. Pada suatu daerah pelosok tersebut terdapat beberapa bahasa yang identik di setiap desa, menyesuaikan suku apa yang dominan di desa tersebut. Untuk itu agen memerlukan orang asli dari daerah tersebut untuk membantu menerjemahkan ke bahasa mereka, karena masih ada juga masyarakat yang tidak mengerti Bahasa Indonesia. Hal ini menjadi salah satu alasan mengapa BPJS Ketenagakerjaan membutuhkan kemitraan dengan Agen Perisai karena bukan hal yang mudah untuk masuk ke daerah tertentu jika kita tidak menguasai bahasa di daerah tersebut. Berbeda halnya ketika orang daerah itu sendiri yang menyampaikai program/ sosialisasi, tentu masyarakat daerah tersebut akan lebih mudah mengerti dan percaya akan hal yang disampaikan.

Pada saat melakukan sosialisasi menurut seluruh informan, jika ada pertanyaan yang belum dikuasai maka mereka akan berusaha menjawabnya dengan semaksimal mungkin. Apabila informan tidak dapat menjawab, maka mereka menampung pertanyaan tersebut dan kemudian meneruskannya ke kantor cabang.

Kendala lainnya yaitu terkait fasilitas/ kit untuk sosialisasi berupa brosur. Brosur yang berisi manfaat terbaru hingga hari ini belum tersedia di kantor cabang, padahal kenaikan 
manfaat program BPJS

Ketenagakerjaan sudah dilaksanakan sejak Desember 2019. Beberapa agen menyayangkan hal tersebut karena bagi agen brosur adalah salah satu "senjata tempur" bagi mereka ketika berhadapan langsung dengan calon peserta. Pada tahap ini masih terdapat beberapa agen yang merasa kurang percaya diri saat menghadapi banyak orang meskipun telah menguasai produk/ program BPJS Ketenagakerjaan. Ketersediaan brosur juga menjadi salah satu kendala bagi informan.

4. Tahap Mengatasi sanggahan, komplain, keberatan

Berdasakan hasil wawancara yang saya dapat dari informan, bahwa tidak ada kendala yang berarti saat mengahadapi sanggahan, komplain, maupun keberatan. Dari beberapa agen, peneliti dapati jika dari awal komunikasi dan terbangun hubungan yang baik apabila terdapat komplain, sanggahan atau keberatan akan lebih mudah untuk ditangani karena telah terdapatnya rasa saling percaya antara agen dan calon peserta/ peserta.

5. Tahap penutupan

Tahap penutupan merupakan salah satu tahap yang krusial, karena pada tahap ini seorang agen harus dapat memancing atau membuat peserta mengambil keputusan untuk segera mendaftarkan diri menjadi peserta. Sebagian informan merasakan jika mereka sulit mengatasi calon peserta yang menunda waktu pendaftaran dengan alasan butuh waktu untuk berpikir atau berdiskusi dengan keluarga. Informan menyampaikan bahwa mereka tidak ingin tampak memaksa, karena khawatir akan membuat calon peserta tidak nyaman dan berpengaruh pada citra agen perisai serta BPJS Ketenagakerjaan di lapangan ke depannya.

6. Tahap Tindak Lanjut dan pemeliharaan

Hasil wawancara peneliti dengan informan, didapati bahwa jarak adalah salah satu kendala dalam tahapan tindaklanjut dan pemeliharaan. Jarak ini merupakan kendala juga pada tahapan prapendekatan. Namun di tahapan ini, jika masyarakat sudah menjadi peserta, agen mengatasinya dengan menggunakan jaringan komunikasi (telpon/ whatsapp). Namun, jika daerah tersebut jaringan komunikasinya tidak stabil biasanya dari agen memilih satu orang koordinator dari daerah tersebut sebagai jembatan antara peserta dan agen. Keterbatasan akses kanal pembayaran juga menjadi salah satu kendala yang dihadapi oleh agen.

Secara keseluruhan tahapan personal selling memiliki peran yang sangat besar terhadap purchase intention konsumen, dimana persepsi konsumen terhadap sales person termasuk kemampuannya dalam menarik perhatian konsumen telah mempengaruhi niat konsumen untuk melakukan pembelian (Sukmana, 2017). Gunasekaran dkk, (2015) menggunakan empat indikator untuk mengukur efektivitas personal selling dalam meningkatkan minat konsumen untuk melakukan pembelian yaitu Kemampuan Komunikasi (Communication Ability), Pengetahuan Produk (Product Knowledge), Kreativitas (Creativity), Empati (Empathy). Berdasarkan hasil wawancara secara mendalam dengan informan, penulis mendapati bahwa 
empat indikator diatas memiliki peranan penting dalam pelaksanaan personal selling oleh agen perisai yang akan diuraikan sebagai berikut :

\section{Kemampuan \\ Komunikasi}

(Communication Ability)

Kemampuan berkomunikasi baik dalam pelaksanaannya tidak hanya berkaitan dengan cara berbicara dan menggunakan bahasa yang baik, sikap dan pembawaan dari agen pun tentu berpengaruh dalam komunikasi dengan calon peserta. Kesan awal yang didapat oleh peserta juga akan mempengaruhi kesan instansi yang diwakili, dalam hal ini adalah BPJS Ketenagakerjaan.

Kemampuan komunikasi yang baik juga akan menumbuhkan rasa percaya dalam pengambilan keputusan oleh calon peserta pada akhirnya. Setiap agen memiliki kemampuan komunikasi yang khas dan berbeda. Meskipun sangat penting, namun kemampuan tersebut dapat dipelajari dan ditingkatkan jika agen dirasa masih kurang dalam hal ini. Pembinaan oleh ARK dibutuhkan agar agen tersebut dapat memenuhi standar yang diharapkan dan merepresentasikan citra instansi dengan baik. Peran agen dalam hal ini yaitu agen harus memperbesar kapasitasnya dalam kemampuan komunikasi dengan terus belajar dan aktif berkomunikasi dengan agen lainnya untuk saling berbagi ilmu yang dimiliki.

2. Pengetahuan Produk (Product Knowledge)

Pengetahuan produk dapat digambarkan sebagai "senjata" bagi agen dalam mengakuisisi kepesertaan di lapangan. Pengetahuan produk yang memadai sangat dibutuhkan untuk meyakinkan calon peserta bahwa mereka membutuhkan produk ditawarkan. Kurangnya pengetahuan juga akan membuat calon peserta kurang yakin dengan produk yang ditawarkan oleh tenaga penjual. Hal ini dapat diatasi dengan lebih banyak mempelajari terkait produk BPJS Ketenagakerjaan. Banyaknya pertanyaan yang diterima dari calon peserta juga secara tidak langsung akan meningkatkan pengetahuan produk. Peran kantor cabang dalam hal ini yaitu dengan mengadakan pembinaan rutin secara personal maupun pertemuan dengan seluruh agen yang dilakukan secara berkala. Bekal awal terkait pengetahuan produk, diterima agen perisai saat pelatihan agen perisai yang dilaksanakan oleh Kantor Cabang.

\section{Kreativitas (Creativity)}

Kreativitas merujuk pada keterampilan sales person dalam memasarkan produk, menggunakan berbagai metode komunikasi dalam menarik perhatian konsumen, serta memiliki kesabaran ketika menawarkan produk kepada konsumen. Kreativitas agen akan menunjang kinerja dilapangan dan dapat memaksimalkan hasil capaian akusisi. Kreativitas akan menjadi nilai lebih dari seorang agen/ tenaga penjual. Berdasarkan hasil wawancara terdapat beberapa agen yang melakukan inovasi sehingga mempermudah saat akusisi kepesertaan, sebagai berikut :

a. Ibu Cudarsiah (Agen Perisai KC Tarakan)

Ibu Curdasiah memiliki styrofoam/ gabus yang digunakan untuk penyerahan simbolis manfaat program jaminan kematian sebesar Rp. 42.000.000.000,- kepada ahli waris jika terdapat peserta yang meninggal 
dunia. Beliau memajang gabus penyerahan simbolis tersebut di ruang tamu rumahnya, sehingga ketika ada yang bertamu ke rumah biasanya orang-orang akan bertanya. Hal tersebut nampak sederhana, namun secara tidak langsung menjadi alat promosi yang efektif bagi Ibu Curdasiah.

b. Ibu Siti (Agen Perisai KC Batulicin)

Ibu Siti memiliki koneksi dengan asosiasi kepala desa sebelum aktif menjadi agen perisai. Hubungan yang baik dengan seluruh kepala desa menjadi peluang yang bagus untuk $\mathrm{Bu}$ Siti, salah satunya dengan dapat memiliki izin untuk melakukan sosialisasi di setiap desa hingga tingkat kecamatan.

Kreativitas dapat didapatkan dengan sering melakukan sharing dan diskusi dengan agen lain dari wilayah yang sama maupun diluar wilayah Kalimantan. Prinsip ATM (AmatiTiru-Modifikasi) dapat diterapkan dan disesuaikan dengan potensi daerah masing-masing.

4. Empati (Empathy)

Empati merujuk pada kemampuan salesperson untuk memberikan perhatian individual kepada konsumen, sungguh-sungguh mengutamakan kepentingan konsumen dan pemahaman terhadap kebutuhan konsumen serta kemampuan salesperson dalam memberikan solusi terhadap masalah yang dihadapi konsumen. Program BPJS Ketenagakerjaan merupakan bagian dari jaminan sosial dimana Instansi ini pun merupakan lembaga non-profit yang diberikan amanah untuk melindungi seluruh pekerja Indonesia. Empati menjadi salah satu unsur penting dalam pelaksanaan jaminan sosial ketenagakerjaan, karena merupakan ini merupakan hak bagi tenaga kerja. Agen perisai yang mampu menunjukan empati saat komunikasi maupun sosialisasi tentu akan memiliki peluang akusisi yang lebih besar. Masyarakat yang dapat merasakan empati tersebut akan tumbuh rasa percaya dan merasakan kepedulian dari agen/ tenaga penjual.

Dari empat indikator efektifitas diatas, menurut penulis agen yang memiliki kreativitas, mampu menunjukan empati, dan kemampuan komunikasi yang baik maka akan tampil beda dan memiliki nilai lebih dibanding agen lainnya. Ketiga hal tersebut akan menjadi ciri khas dari agen/ tenaga penjual karena bersifat personal, sedangkan kemampuan bicara di publik (public speaking) dan pengetahuan produk adalah sesuatu yang dapat ditingkatkan dengan pembelajaran.

Upaya Penanganan Kendala oleh Kantor Cabang dalam Pelaksanaan Keagenan Perisai

BPJS Ketenagerjaan dan Agen Perisai merupakan hubungan kemitraan. Dalam pelaksanaannya tentu saja dibutuhkan koordinasi dan sinergi yang baik agar dapat mencapai kinerja yang maksimal. Oleh karena itu, peneliti ingin mengetahui apakah kerjasama yang baik antara kantor cabang dan agennya mempengaruhi hasil capaian akuisisi di lapangan.

Semua informan menyampaikan bahwa Kantor Cabang serta seluruh staff nya sangat membantu jika terdapat kendala-kendala di lapangan misalkan jika informan tidak dapat menjawab pertanyaan dari peserta. Kendala aplikasi pun, jika terjadi 
gangguan, dari Kantor Cabang siap sedia untuk mengatasi kendala tersebut.

Adapun dalam setiap kendala yang dihadapi di lapangan, agen perisai selalu berkoordinasi dengan kantor cabang. Pada awalnya saat menjadi agen baru, Kantor Cabang dalam hal ini diwakili oleh ARK (Account Representative Khusus) akan melakukan pembinaan/ pendampingan penuh terhadap agen perisai. Pembinaan ini berupa pelatihan awal mengenai pengetahuan produk, penggunaan aplikasi, hingga pendampingan sosialisasi. ARK juga melakukan pembinaan dengan menginfokan strategi yang dapat dilakukan saat di lapangan.

Pendampingan saat sosialisasi dilakukan agar agen dapat mengamati bagaimana cara melakukan sosialisasi/ demonstrasi di depan orang banyak. Pelatihan terkait berbicara di muka publik tentu dibutuhkan, disamping praktek langsung di lapangan. Pada saat baru menjadi agen biasanya masih banyak hal yang baru dipelajari, yang mengakibatkan agen tersebut belum mampu beberapa pertanyaan dari masyarakat. Peran aktif ARK sangatlah penting dalam konsultasi dan koordinasi pada fase babysitting ini karena materi yang didapat dalam kelas pelatihan belum cukup untuk menjawab pertanyaan/ keluhan dengan case khusus. Namun, seiring dengan semakin banyaknya pertanyaan dari peserta dengan berbagai macam kondisi, agen tersebut akan semakin terlatih dan andal dalam menanggapi pertanyaan dari masyarakat.

Monitoring dan evaluasi (Monev) secara rutin juga merupakan salah satu unsur penting dalam upaya menjaga sinergitas dengan agen perisai di lapangan. Dalam kegiatan monev ini pembahasannya berupa capaian kinerja dari setiap agen, kendala dilapangan, hingga sharing kiat-kiat yang digunakan oleh agen-agen dengan kinerja terbaik. Rutinitas monev ini akan membuat kegiatan agen dilapangan dapat terpantau mulai dari kendala hingga hal-hal yang dibutuhkan (fasilitas) untuk akuisisi kepesertaan di lapangan. Setiap kantor cabang memiliki rutinitas monev yang berbeda, mulai dari setiap bulan, 1 kali dalam 3 bulan, hingga 1 kali dalam 6 bulan. Semakin rutin pembinaan saat monev semakin baik, namun jika secara geografis terdapat kesulitan (jarak dan medan jalan) dapat disesuaikan dalam pelaksanaannya.

Wawancara yang dilakukan penulis dengan informan didapati juga saran-saran ataupun aspirasi untuk pengembangan dan kemajuan keagenan perisai kedepannya. Seluruh informan sekata dalam hal penyempurnaan aplikasi Perisai. Sebagian besar dari informan juga menyampaikan terkait batasan iuran maksimal yang dapat di kelola oleh agen dan presentase insentif iuran dapat ditingkatkan lagi. Beberapa informan pun menyampaikan harapan mereka agar perlindungan mereka sebagai agen perisai dapat ditanggung oleh BPJS Ketenagakerjaan, bukan ditanggung secara pribadi/ perorangan. Hal tersebut disampaikan karena agen juga merupakan ujung tombak akuisisi kepesertaan bagi kantor cabang.

Dalam upaya meningkatkan antusias agen perisai dalam pencapaian kinerja, Kantor Pusat mengadakan Kompetisi Agen Terbaik setiap tahunnya dengan Reward yang sangat 
menarik. Dalam wawancara yang dilakukan peneliti, informan menyampaikan saran agar kriteria penilaian agen terbaik tersebut dapat dilakukan per-kantor wilayah sehingga tidak berpatok hanya pada angka saja. Hal tersebut disampaikan karena dalam prakteknya di lapangan tentu saja tantangan di lapangan di setiap daerah berbeda, seperti di perkotaan untuk mencapai iuran yang besar bisa jadi lebih mudah daripada di daerah yang bahkan akses untuk ke atm saja terbatas. Informan juga menyampaikan saran agar channel pembayaran iuran BPJS Ketenagakerjaan dapat semakin diperluas seperti melalui Kantor pos maupun Pegadaian, karena di daerah pelosok seringkali kesulitan untuk akses pembayaran.

BPJS Ketenagakerjaan juga melakukan sertifikasi profesi bagi agen-agen yang memenuhi kriteria tertentu (seperti capaian akuisisi, iuran, hingga keberlanjutan bayar). Pada wawancara, informan memberikan saran agar setiap agen yang telah sertifikasi mempunyai nilai lebih di bandingkan dengan agen yang belum tersertifikasi seperti kenaikan insentif/ fee bagi agen perisai. Hal tersebut diharapkan dapat memacu semangat agen perisai lebih lagi untuk mempertahankan bahkan meningkatkan capaian kinerjanya.

\section{Kesimpulan}

Strategi personal selling telah digunakan oleh agen perisai di wilayah kalimantan. Adapun tahapannya yaitu : prospek, pra-pendekatan, tahap sosialisasi dan demonstrasi, mengatasi keberatan, penutupan, dan tindak lanjut pemeliharaan. Prospek, pada tahapan ini agen menggunakan strategi dengan mengandalkan relasi yang dimiliki untuk mengidentifikasi calon peserta yang potensial dan bersinergi dengan organisasi maupun instansi pemerintah untuk dapat menjangkau calon peserta secara massal. Pada tahapan prapendekatan, agen-agen sekata dalam pemilihan cara berkomunikasi yaitu menggunakan percakapan informal agar lebih mudah diterima oleh masyarakat perorangan. Tahap presentasi dan demonstrasi, pada tahap ini dapat disimpulkan untuk sosialisasi ke calon peserta perorangan, agen berusaha menjelaskan dengan bahasa yang paling sederhana agar mudah dimengerti oleh berbagai kalangan. Sedangkan untuk kepesertaan badan usaha bentuknya lebih ke arah mengedukasi mengenai pentingnya dan kewajiban jaminan sosial bagi karyawan yang dipekerjakan. Mengatasi keberatan, kesimpulan yang dapat diambil di tahap ini setiap agen akan menampung pertanyaan yang belum bisa dijawab dan meneruskannya ke kantor cabang. Agen berusaha menyimak dengan seksama apa yang menjadi keberatan dari calon peserta tersebut dan kemudian menjelaskan dengan detail pokok permasalahannya. Hubungan dan komunikasi baik yang terbangun sejak awal akan membuat calon peserta bersedia mendengarkan dan lebih mudah mengerti yang disampaikan. Tahap penutupan, kesimpulan yang dapat diambil pada tahapan ini yaitu agen menyajikan testimoni dari peserta yang telah menerima manfaatnya serta menciptakan rasa butuh bagi calon peserta. Penyampaian persyaratan sebelum sosialisasi pun akan mempermudah proses closing di tempat. Tahap tindak lanjut dan pemeliharaan pada tahapan ini seluruh 
agen perisai siap untuk memberikan pelayanan berupa sistem "jemput bola" dari tahapan pendaftaran hingga pengelolaan kepesertaan yang akan berdampak pada meningkatnya loyalitas peserta

Setiap agen memiliki kendala masing-masing pada tiap tahapan personal selling. Pada tahapan prospek, beberapa agen merasa kurang representatif, karena belum adanya seragam resmi dari kantor pusat yang disediakan khusus agen perisai. Pada tahapan selanjutnya, yaitu prapendekatan. Tantangan geografis dan jaringan komunikasi menjadi penghambat terutama di daerah-daerah pelosok. Biaya operasional menjadi salah satu kendala. Citra instansi dan asuransi swasta pun berdampak pada tahapan ini. Sosialisasi dan demonstrasi, pada tahapan ini komunikasi dan penggunaan bahasa daerah menjadi kendala dalam pemahaman masyarakat tentang program BPJS Ketenagakerjaan. Keterbatasan brosur pun menjadi kendala lainnya saat sosialisasi di lapangan. Beberapa agen masih merasa kurang percaya diri saat sosialisasi di hadapan banyak orang. Pada tahapan sanggahan tidak terdapat kendala yang berarti bagi agen perisai. Namun pada tahapan penutupan, masih terdapat agen yang merasa segan ketika konfirmasi keputusan untuk mendaftar. Tahapan tindaklanjut dan pemeliharaan, memiliki kendala sama seperti tahapan prapendekatan yaitu jarak dan komunikasi. Keterbatasan kanal bayar juga menjadi kendala dalam keberlanjutan pembayaran iuran peserta.

Berdasarkan hasil wawancara, kantor cabang berperan aktif dalam penanganan kendala yang dialami agen di lapangan mulai dari kendala teknis seperti aplikasi, penyediaan seragam lapangan, hingga menyediakan kelengkapan untuk sosialisasi. Pelatihan, pembinaan dan pendampingan harus dilakukan secara intens oleh ARK dan Kantor Cabang guna memastikan pelaksanaan keagenan perisai dapat berjalan dengan baik dan maksimal di lapangan.

\section{Daftar Pustaka}

Arianto, Bimo. 2017. Menakar Keberhasilan Penyelenggaraan Jaminan Sosial. Jurnal Institut BPJS Ketenagakerjaan Tahun 2017. Volume 2, pp 51-90.

BPJS Ketenagakerjaan, 2017. Tingkatkan Peserta, BPJS Ketenagakerjaan Bentuk Agen Perisai, https://www.bpjsketenagakerjaan .go.id/berita/13869/TingkatkanPeserta,-BPJS-KetenagakerjaanBentuk-Agen-Perisai (diakses pada tanggal 27 Februari 2020).

BPJS Ketenagakerjaan, 2017. BPJS Ketenagakerjaan Luncurkan Program Perisai Rekut Tenaga Kerja Nonformal, https://www.bpjsketenagakerjaan .go.id/ berita/18029/BPJS-

Ketenagakerjaan-luncurkanProgram-Perisai-Rekut-TenagaKerja-Nonformal (diakses pada tanggal 27 Februari 2020).

BPJS Ketenagakerjaan, 2015. Tentang Kami - Sejarah, https://www.bpjsketenagakerjaan.go.id/sejarah.html (diakses pada tanggal 27 Februari 2020).

Finansialku, 2017. BPJS Ketenagakerjaan Menggaet 
Banyak Peserta Melalui Agen Perisai, https://www.finansialku.com/bpj s-ketenagakerjaan-meraihbanyak-peserta-melalui-agenperisai/ (diakses pada tanggal 27 Februari 2020).

Hermawan, Agus. 2012. Komunikasi Pemasaran. Jakarta, Erlangga.

Kompas, 2016. "Personal selling" : Komunikasi Mesra Para Pemasar, https://money.kompas.com/read/ 2016/06/20/193333326/.personal selling.komunikasi.mesra.para.p emasar.?page=all. (diakses pada tanggal 27 Februari 2020).

Kotler, Philip. 2008. Manajemen Pemasaran. Edisi 12 Jilid 2. Indeks, Jakarta.

Kotler, Philip and Gary Armstrong. 2012. Prinsip-Prinsip Pemasaran. Edisi 13. Jilid 1. Erlangga, Jakarta.

Morissan, M.A. 2010. Periklanan : Komunikasi Pemasaran Terpadu. Kencana, Jakarta.
Silaban, Rekson, \& Badikenita. 2017. Perluasan Kepesertaan BPU BPJS Ketenagakerjaan melalui Strategi Marketing mix dan Regulasi. Jurnal Institut BPJS Ketenagakerjaan Tahun 2017. Volume 2, pp 1-50.

Sugih, P. 2020. Konsep Marketing: Pengertian, Jenis, dan Bedanya dengan Konsep Penjualan, https://accurate.id/marketingmanajemen/pembahasanlengkap-konsep-marketing/ (diakses pada tanggal 27 Agustus 2020)

Sukmana, DF. 2017. Pengaruh Personal selling Dan Brand Activation Terhadap Purchase Intention Konsumen pada Produk Santan Bubuk Sasa PT Sasa Inti di Surabaya. Tesis. Program Manajemen Pemasaran. Universitas Kristen Petra, Surabaya.

Tjiptono, Fandy. 2002. Strategi Pemasaran. Penerbit Andi, Yogyakarta. 